Portland State University

PDXScholar

\title{
Social Studies in the Modern Era: A Case Study of Effective Teachers' Use of Literacy and Technology
}

\author{
Kristal Curry \\ Coastal Carolina University \\ Todd Cherner \\ Portland State University, chernert@pdx.edu
}

Follow this and additional works at: https://pdxscholar.library.pdx.edu/ci_fac

Part of the Curriculum and Instruction Commons, and the Educational Methods Commons Let us know how access to this document benefits you.

\section{Citation Details}

Curry, Kristal and Cherner, Todd, "Social Studies in the Modern Era: A Case Study of Effective Teachers' Use of Literacy and Technology" (2016). Curriculum and Instruction Faculty Publications and Presentations. 34.

https://pdxscholar.library.pdx.edu/ci_fac/34

This Post-Print is brought to you for free and open access. It has been accepted for inclusion in Curriculum and Instruction Faculty Publications and Presentations by an authorized administrator of PDXScholar. Please contact us if we can make this document more accessible: pdxscholar@pdx.edu. 


\section{Social Studies in the modern era: A case study of effective teachers' use of literacy and technology}

When the College, Career, and Civic Life (C3) Framework ${ }^{1}$ was introduced by the National Council of Social Studies, it issued a challenge to all social studies teachers to design more rigorous instruction. Implicit in this challenge is an understanding that if social studies is to remain relevant, it needs to move into the "modern era." This modern era includes a renewed emphasis on the literacy skills and practices needed for "College and Career Readiness," as well as the ability to deftly incorporate technology. While the $\mathrm{C} 3$ framework provides examples for how to utilize technology that promotes college and career readiness, the challenge of balancing the demands placed on teachers by curriculum requirements (e.g., pacing guides and state standards) and accountability measures (e.g., end-of-course exams and standardized, high stakes assessments) remains. This context led the authors to conduct a case study that examined how a select group of "effective" social studies teachers incorporate literacy and technology expectations into the instruction they provide students.

The purpose of this research project was to highlight both the practices and philosophies of effective - but different - social studies teachers who balance the demands of teaching in the modern era while honoring their own philosophies of teaching social studies. The overall research question the study's researchers asked was: How are practicing social studies teachers who are considered "effective" integrating technology and literacy into their teaching practice? Secondary questions broke this down into smaller parts that include:

\footnotetext{
${ }^{1}$ National Council for the Social Studies, The College, Career, and Civic Life (C3)Framework for Social Studies State Standards: Guidance for Enhancing the Rigor of K-12 Civics, Economics, Geography, and History (Silver Spring, MD: NCSS, 2013).
} 
- What does it mean to be an effective social studies teacher?

- How and why are these effective teachers incorporating literacy?

- How and why are they using technology?

- How are they able to balance their philosophies of teaching social studies with the demands that they incorporate literacy and technology into their instruction?

This paper begins with an overview of the Technological Pedagogical and Content Knowledge framework (TPACK) which was this study's guiding theory. Next, this study's methodology, participants, and context are presented. Finally, the study's findings and implications are discussed.

\section{Theoretical Framework TPACK}

In the 1980s, Shulman ${ }^{2}$ argued teachers must align their pedagogical content knowledge bases in order for classroom instruction to be meaningful. Shulman's work resulted in the Pedagogical Content Knowledge framework (PCK, Figure 1), and it was widely adopted by fellow teacher educators and researchers ${ }^{3}$.

\footnotetext{
${ }^{2}$ L.S. Shulman, "Those Who Understand: Knowledge Growth in Teaching," Educational Researcher 15, no. 2 (1986). L.S. Shulman, "Knowledge and Teaching: Foundations of the New Reform," Harvard Educational Review 57 (1987).

${ }^{3}$ K. F. Cochran, J.A. Deruiter, and R.A. King. "Pedagogical Content Knowledge: An Integrative Model for Teacher Preparation," Journal of Teacher Education 44 (1993).

J. H. Van Driel, N. Verloop, and W. de Vos, "Developing Science Teachers' Pedagogical Content Knowledge," Journal of Research in Science Teaching 35, no. 6 (1998).

S. Magnusson, J. Krajcik, and H. Borko, "Nature, Sources, and Development of Pedagogical Content Knowledge for Science Teaching," in Examining Pedagogical Content Knowledge, ed. J. Gess-Newsomen \& N. G. Ledermen, (Netherlands: Springer, 1999).
} 
The ubiquity of technology as represented by smartphones, tablet devices, and laptop computers have created a paradigmatic change in societies across the globe ${ }^{4}$. In response, Koehler and Mishra ${ }^{5}$ reorganized PCK so it included technology. The result of their work was TPACK, as depicted in Figure 2.

TPACK includes three main components: Content Knowledge, Pedagogical Knowledge, and Technological Knowledge. Koehler and Mishra explain content knowledge as the "teachers' knowledge about the subject matter to be learned or taught [that includes] concepts, theories, ideas, organizational frameworks, knowledge of evidence and proof, as well as established practices and approaches toward developing such knowledge." As has been well documented, teachers must have deep content knowledge if they are to effectively explain their subject matter to students. ${ }^{7}$ Based on Koehler and Mishra's work, teachers must have a firm grasp of their discipline's subject matter if they are going to design meaningful learning experiences, which connect to their Pedagogical Knowledge.

Pedagogical Knowledge represents teachers" understanding of "the processes and practices or methods of teaching and learning [including] issues of student learning, classroom

${ }^{4}$ T. S. Kuhn, The Structure of Scientific Revolutions, (Chicago, IL: University of Chicago Press, 2012).

${ }^{5}$ M. Koehler and P. Mishra, "What is Technological Pedagogical Content Knowledge (TPACK)?” Contemporary Issues in Technology and Teacher Education 9, no. 1 (2009).

${ }^{6}$ Ibid., p. 63

7 K. Haycock, "Good Teaching Matters: How Well-Qualified Teachers Can Close the Gap," Thinking K-16 3, no. 2 (1998).

S. Hausfather, "Where's the Content? The Role of Content in Constructivist Teacher Education," Educational Horizons 80, (2001).

D. Sparks, "The Looming Danger of a Two-Tiered Professional Development System," Phi Delta Kappan 86, no. 4 (2004). 
management, lesson plan development and implementation." ${ }^{\text {8 }}$ Pedagogical Knowledge then is a hollow shell representing the considerations teachers must attend to when designing and implementing a lesson. Teachers fill in that shell by combining their content knowledge with their pedagogical knowledge to create meaningful learning experiences that prepare students for college and the workforce.

Cherner and $\mathrm{Smith}^{9}$ operationalized these generic pedagogical strategies that require students to read, write, and collaborate as "literacy strategies" in their reconceptualization of TPACK. For example, a think-pair-share (TPS) teaching strategy is commonly used across the content areas to have students first engage a topic individually (think), then with a classmate or small group (pair), and then report out to the class community (share). ${ }^{10}$ A TPS by itself is pedagogical because it frames a generic teaching strategy. When teachers add their content knowledge, it becomes content specific pedagogy. Returning to TPS example, if a social studies teacher had her students compare a primary and secondary source related to the same event individually using a Venn diagram and then combine their comparisons with a partner before taking part in a class conversation about those comparisons, that activity represents that teacher's Pedagogical Content knowledge because she is combining the two knowledge bases pedagogical and content - to create a content-specific learning activity. Though the TPS uses general collaborative and literacy strategies, it becomes content-area specific because the teacher

\footnotetext{
${ }^{8}$ P. Mishra and M.J. Koehler, "Technological Pedagogical Content Knowledge: A Framework for Integrating Technology in Teacher Knowledge," Teachers College Record 108, no. 6 (2006), p. 1026-1027.

${ }^{9}$ T. Cherner and D. Smith, "Reconceptualizing TPACK to Meet the Needs of $21^{\text {st }}$ Century Education," (in press, The New Educator, 2015)

${ }^{10}$ N.N. Azlina and A. Nik, "CETLs: Supporting Collaborative Activities Among Students and Teachers Through the Use of Think-Pair-Share Techniques," International Journal of Computer Science Issues 7, no. 5 (2010). J. McTighe and F.T. Lyman, "Cueing Thinking in the Classroom: The Promise of Theory-Embedded Tools," Educational Leadership 45, no. 7 (1988).
} 
has her students deeply engaging texts that are used in social studies. This TPS can be further enhanced with TPACK's final component.

Technological Knowledge consists of teachers' abilities to understand and operate both standard technologies (e.g., chalkboards, textbooks, timers) and emerging technologies (e.g., tablets, software, and smartphones). ${ }^{11}$ Koehler and Mishra further explain that Technological Knowledge "enables a person to accomplish a variety of different tasks using information technology and to develop different ways of accomplishing a given task."12 Given that technology is always evolving, the importance is not on learning how to operate just one type of technology; rather, the emphasis is focused on teachers knowingly selecting and using different technologies to enhance student learning and productivity.

Returning to the TPS example, the teacher can enhance it by loading digital copies of the resources as PDF files into the Adobe Reader app and a blank Venn diagram into Google Drive that students can access. During the "think" activity, students can read and annotate each of the resources' key points in the app and then transfer that information into the Venn diagram on Google Drive.. Next, students can "pair" together and share the link to their Venn diagram with their groupmates, which lets groupmates access and modify each other's work. When students are ready to "share" their work with the class, they can send their teacher a link to it so it can be projected or they can post a link to a class website. The teacher can then decide how she wants students to present their work or how she wants students to respond to their peers' work. Using technology in these capacities increases the accessibility and collaboration components of the

\footnotetext{
${ }^{11}$ P. Mishra and M.J. Koehler, "Technological Pedagogical Content Knowledge: A Framework for Integrating Technology in Teacher Knowledge," Teachers College Record 108, no. 6 (2006)

${ }^{12}$ M. Koehler and P. Mishra, "What is Technological Pedagogical Content Knowledge (TPACK)?" Contemporary Issues in Technology and Teacher Education 9, no. 1 (2009), p. 64.
} 
TPS, and the TPS described in this section represents an activity that drew from TPACK's different components.

TPACK frames teachers' knowledge bases into overlapping compartments, and the center of the overlap is intended to represent the type of 21 st century teaching that promotes readiness for college, career, and civic life as described by the C3 Framework. Mishra and Koehler explain that TPACK is:

"The basis of good teaching with technology and requires an understanding of the representation of concepts using technologies; pedagogical techniques that use technologies in constructive ways to teach content; knowledge of what makes concepts difficult or easy to learn and how technology can help redress some of the problems that students face; knowledge of students' prior knowledge and theories of epistemology; and knowledge of how technologies can be used to build on existing knowledge and to develop new epistemologies or strengthen old ones"13

Using TPACK as an instructional frame allows a method for analyzing teaching based on its disparate but still interconnected components. When instructional gaps are present in a teacher's lesson, TPACK provides a frame to signify where the instruction was strong and how it could be improved. This analysis can be completed through reflection of one's own performance in the classroom or by an outside observer who is evaluating or mentoring a teacher. In these instances, the importance is not to use TPACK as a checklist for teacher evaluation; instead, it is that teachers are designing and implementing lessons that blend TPACK's components into a meaningful learning experience for students.

\footnotetext{
${ }^{13}$ P. Mishra and M.J. Koehler, "Technological Pedagogical Content Knowledge: A Framework for Integrating Technology in Teacher Knowledge," Teachers College Record 108, no. 6 (2006), p. 1029.
} 
Methodology and Participants

$\underline{\text { Methodology }}$

This project used a case study methodology ${ }^{14}$ with the bounded unit defined as a group of three social studies teachers from one high school. The project's purpose was to understand how these teachers incorporated literacy and technology into their instruction, while honoring their own ideals for teaching social studies. The researchers conducted interviews with each participant, and the interviews averaged 45 minutes in length. An open-ended interview protocol was designed to guide participants in their discussion of the phenomena of interest (literacy, technology, and philosophy of teaching social studies, see Appendix 1) ${ }^{15}$. After the interviews, each participant was observed three times in the classroom (each observation lasted 90 minutes, which was the length of a "block" in this school). The researchers took detailed observation notes in addition to filling in an observation protocol focusing on the areas of interest for the study (See Appendix 1). Data consisted of the following: transcriptions of the three recorded interviews and interview notes, and observation protocols, notes, and other documents (including assignments given to students) collected during observations.

All interview and observation files were then imported into Nvivo 10, a computer program designed for qualitative data analysis. Each piece of data was classified by the name of the participant. Classifying the data this way allowed for themes to be identified that were

${ }^{14}$ R. K. Yin, Case study research: Design and methods. $3^{\text {rd }}$ edition (Thousand Oaks, CA: Sage Publications, 2003).

${ }^{15}$ Phillip Carspecken, Critical Ethnography in Educational Research: A Theoretical and Practical Guide (New York: Routledge, 1996). 
specific and significant to each participant individually before looking across the data for broader themes that encompassed all three participants. We combed through each document using the constant comparative method ${ }^{16}$ beginning with open coding, and then generating categories.

\section{The Setting}

The context of this study is particularly significant because the three teachers all worked in a single, non-traditional high school. This high school's mission is to enroll diverse, underrepresented students who score in the middle quartiles on test performance and provide them the preparation and experiences needed to be successful in college and beyond. The school enrolls 400 students in grades 9-12, and it is located in a new building on the grounds of a community college. Students in their junior and senior years are permitted to take a combination of high school and community college courses, and they can earn up to two years of college credit, according to the school's website.

The school is selective in its hiring, and it is generous in terms of providing professional development and technology for its teachers. All three teachers took advantage of the available professional development—-for example, one of them was invited to the state capital to develop the new state standards for U.S. History, another was funded for a Summer Workshop for Educators at the National Archives in Philadelphia, and the other was able to take a multi-day Civil Rights tour of the South. All three mentioned the generosity of their school (and district) in terms of funding professional development and how these opportunities made them better, more

\footnotetext{
${ }^{16}$ B.G. Glaser and A. L. Strauss. Discovery of Grounded Theory: Strategies for Qualitative Research (Chicago: Aldine Publishing Company, 1967).
} 
confident teachers. Plus, the school district that employs these teachers has purchased tablet devices for all their elementary, middle, and high school students and teachers to use.

Admittedly, the context in which these teachers worked is very specific and in many ways, quite ideal as exemplified by its investment in its teachers and technology. Because the participants work in a school that serves a diverse student population and have had unique experiences with professional development and instructional technology, much knowledge can be gained from studying their beliefs and practices as related to social studies education and the C3 framework.

\section{The Participants}

From the early stages of this project, we sought to capture good teaching organically, with an emphasis on the ways effective teachers are able to incorporate literacy and technology into their courses while maintaining the integrity of social studies content. We, therefore, began searching for participants by visiting the District-Level Social Studies Coordinator and asking for recommendations. The coordinator made her recommendation of the three participants used in this study. However, it was important to us that measures beyond the Coordinator's recommendation were used to identify effectiveness in the participants.

As a "teacher-effectiveness" guide, we used ASCD's Qualities of Effective Teachers checklist. ${ }^{17}$ While there is clearly no single correct definition of an "effective teacher," ASCD's Qualities of Effective Teachers guide provided a useful method for establishing the quality of the

${ }^{17} \mathrm{~J} . \mathrm{H}$. Stronge, Qualities of Effective Teachers, $2^{\text {nd }}$ edition. (Alexandria, VA: Association for Supervision and Curriculum Development, 2007). 
teachers in this study using observable measures from the interviews and observations conducted. It incorporates elements of the teacher as:

1. Person: caring, motivating, reflective, involved in professional development

2. Classroom Manager: utilizing appropriate management skills and routines

3. Lesson Planner: using good resources, maximizing time and organizing lessons effectively

4. Lesson Implementer: meeting needs of a variety of students and using a variety of instructional strategies

5. Assessor: reflecting on student assessments, using assessments to differentiate. Following interviews and classroom observations, we determined each teacher met the criteria for being "effective" according to the definition used in this study, and Table 1 shows how each participant met the criteria for effective teachers.

Lisa. Lisa taught $9^{\text {th }}$ grade Civics. During Lisa's interview and observations, it became clear that while Lisa could teach using a variety of different strategies, her preference was for project-based learning. Specifically, Lisa preferred large-scale projects with many moving parts that require students to work together to succeed. During the study, for example, her students participated in both Project Citizen and National History Day competitions.

Jeff. Jeff taught $10^{\text {th }}$ grade Government. In his instruction, Jeff emphasized the history of American Government, especially the founding documents. Jeff's lessons are studies in precision, with every element building on top of the previous element, every activity specifically timed and defined, and a clear and stated focus and objective for every assignment and assessment. 
Jacob. Jacob taught $11^{\text {th }}$ grade American History (an end-of-course tested subject). Although he indicated using of a wide variety of teaching methods (including National History Day participation) in his interview, Jacob only implemented online units (for an excerpt, see Appendix 2) during our observations. These units required students to individually read, analyze, and process primary and secondary sources that built on each other leading toward a final, overall unit assignment.

\section{Findings}

One of the study's most important findings was that each teacher included elements of technology and literacy differently. All three teachers were effective teachers, but all three teachers used literacy and technology to support their teaching in different ways. Findings will be reported by participant to highlight their similarities and differences.

\section{Lisa: Informed Citizenship}

Teaching Philosophy. Throughout her interview and observations, the most common theme that emerged for Lisa was her belief that social studies should teach students relevant skills needed for being good citizens (see Table 2: Philosophies of teaching social studies). During her interview, she clearly stated this belief: "When students graduate, the goal is, hopefully, to have good citizens, people who can participate in a Democracy, can add to the debate, that aren't easily fooled by charlatans and demagogues, and can actually vote for people based on actual reasons, and not just what the latest newsfeed is."

In Lisa's classroom, students were introduced to the idea of informed citizenship, both overtly through their participation in Project Citizen and covertly through her pedagogical choices. Project Citizen is a major national project that took several weeks of class time to 
complete, and its stated purpose is "promoting competent and responsible participation with government at all levels. The program helps participants learn how to monitor and influence public policy while developing support for democratic values and principles, tolerance, and feelings of political efficacy." 18

During our observational period, students were working on their group Project Citizen reports. Shortly before we arrived, Lisa's students completed and presented projects for the local National History Day competition, suggesting that our observational sessions captured Lisa's preferred pedagogical strategy: using large-scale projects to teach students how to cooperate in small groups while introducing smaller, individual skills to boost content knowledge. This pedagogical style is heavily influenced by her philosophy that teaching social studies is about promoting citizenship. Lisa insisted that within their small groups, all students should be held accountable for how their actions impacted the group. This was a deliberate pedagogical decision on her part. During group work time, Lisa spent the entire class period circulating the room, talking not only with each group, but each individual. She prompted discussion by asking students questions such as: "What are you contributing today? How does that fit into the overall project?" Students were expected to learn to work together and were not allowed to have a day of non-involvement. Responsibility to the group was repeatedly emphasized in her individual discussions with students. During her interview, she stated, "In class, I focus on them as a student, an individual, and then show them how they play a part in this society." That scaffolding structure demonstrates her belief that social studies is about the promotion of social responsibility, and she held students in their groups accountable.

18 "Project Citizen Overview," Center for Civic Education, last modified 2014, http://www.civiced.org/pc-program. 
Technology Use: Given that "informed citizenship" is her teaching philosophy, it makes sense that she used technology in her course primarily to support the goals of collaboration and citizenship (See Table 3: Uses of technology). Students used web-based tools such as Google Drive for a variety of purposes, including Silent Seminars (in which the teacher and students individually answered questions in real time on the same Google Document - allowing for a full, rich discussion without a single spoken word) and group project documents and reports (where all the work done by each individual in a small group was stored for ready for access by all). In our interview, Lisa specifically cited Google Drive as a tool she uses because it "really promotes the idea of students learning from each other." (See Table 5: Perceived limitations and uses of technology). Students also used technology to research current policies related to their Project Citizen reports and to contact policymakers and others who could support or assist them in their projects.

One of the prominent themes throughout the interview with Lisa was that while technology made many of these processes easier, she found some of the limitations of technology concerning, especially those related to the democratic purpose of schools (See Table 5: Perceived limitations and uses of technology). Lisa cited concerns regarding student access. "We have a disparity with the kids that have technology all day long here, but when they go home... nothing," especially as it concerns their ability to keep up with their peers. Lisa was also insistent that technology not be used in place of good teaching, that technology was a tool not for engagement but for learning. As she stated: "The students can be engaged [on the tablets] all day long, but that doesn't mean they're achieving." Her overall view of technology was that it should aid in the processes of collaboration and research, and these views are consistent with her teaching and pedagogy philosophies for social studies. 
Pedagogical Strategies. Students in Lisa's class were expected to locate, read, analyze, and synthesize difficult documents such as current policies and reports on their civic issue as part of their Project Citizen projects. Additionally, at the conclusion of their projects, students were expected to collaborate on a full report including an annotated bibliography and an original interpretation of the available evidence based on their synthesis of a wide variety of sources. The final step of the project was to use their researched policies and students' interpretations to suggest a local policy that might solve the civic issue the class selected. (See Table 4: Uses of literacy, for examples and to compare Lisa's responses with the other participants). This project therefore represents a combination of levels of Depth of Knowledge, heavily favoring levels 3 and 4 (Synthesizing information from multiple sources, identifying and justifying a solution, and designing a policy to solve a civic issue). ${ }^{19}$

The Silent Seminar we observed was mentioned in Lisa's interview as part of a group of content-specific literacy strategies that requires students to write in order to help them understand because "it's then [in writing] when you understand what the kids did or did not get out of it." During her interview, Lisa discussed how many of her students often had difficulty writing. To support them, Lisa explained how she uses low-stakes, informal writing supports such as Cornell notes, outlines, significant summaries, close readings, paraphrasing, and illustrations of key concepts, because: “it's an easy strategy for them to do, as long as they're taking the words and putting them into their own thought process, whatever that ends up looking like." Lisa's use of informal writing processes to support her weaker students is also emblematic

\footnotetext{
${ }^{19}$ N.L. Webb, "Depth of Knowledge Levels for Four Content Areas," Orleans Southwest Curriculum Framework, last edited 2012, http://ossucurr.pbworks.com/w/file/fetch/49691156/Norm\%20web\%20dok\%20by\%20subject\%20area.pdf.
} 
of her overall philosophy of teaching - using methods to ensure that all students understand the content and are able to contribute to class equally.

Lisa's teaching style aligns extremely well with the goals of the C3 framework. For example, she teaches using an inquiry-based style that requires students to develop questions prior to their projects and use disciplinary concepts to answer them. Students evaluate sources and use evidence, both as they progress through their project, and when they develop one of their final pieces, the annotated bibliography described above. That said, Lisa prioritizes dimension 4 of the C3 Framework, whereby students communicate conclusions and take informed action. This element requires the disposition of civic responsibility, which undergirds Lisa's beliefs about teaching Social Studies.

\section{$\underline{\text { Jeff: Storyteller }}$}

Teaching Philosophy. While Jeff also used themes such as civic engagement when discussing the purpose of social studies, the most common and distinguishing theme that emerged from his interview and observations is the idea that social studies content is best understood as a story (Table 2: Philosophies of teaching social studies). In his interview, he stated: "My Government class has a huge History component to it in which I tell a lot of stories, I allow my students to interact with Primary Source documents, trying to interpret it. Trying to figure it out." It is important to note the emphasis he placed on understanding of History as a story did not end with his telling or his interpretation, but rather with the implication that this story was open-ended and that students could and should write their own stories about History using the evidence. "I want them to understand that History is about interpretation and History is all about stories. The nice thing is, you can get kids [involved] in the story part." 
In reflecting on our observations, Jeff's classroom provides the best example of the three participants of a typical social studies classroom. While Lisa often used large-scale projects to frame her instruction and Jacob (as described in the next section) experimented with online only formats, Jeff relied largely on daily lessons following a whole-group modeling $\rightarrow$ small-group practice $\rightarrow$ individual work $\rightarrow$ whole-group regroup format. What made his classroom exciting was that his choices for activities he used to teach the content were consistently engaging to students, and the activities wove together current issues, historical questions, problem-solving, and critical thinking. For example, during one observational period, students conducted an "experiment" whereby they analyzed the voting trends from a variety of states in order to predict if the state will vote for the Democratic or Republican presidential candidate in 2016. The whole class then came together with the results of their experiment to predict who might win the 2016 election. The data the class analyzed was in fact the "story" regarding the trends and past experiences of different states' voting histories, which exemplifies Jeff's teaching philosophy.

Technology Use. Jeff's strategies and resources were always precisely and carefully selected to serve a particular purpose, and this may be why he is the only one of the teachers who raised no concerns in his interview about technology use in the classroom. In the above example of the 2016 election experiment, students were given a specific website to go to that listed voting patterns for each state, as opposed to being requested to find this information on their own. By providing specific digital resources, Jeff relieved the issues of access and uneven familiarity with technology that Lisa expressed in her interview.

Jeff's uses for technology largely support the notion of social studies content as a story that needs to be told rather than as facts that need to be remembered (Table 3: Uses of technology). For example, during one observation, students were introduced to a project whereby 
they would create a documentary about "We the People" that required them to explain what this concept (e.g., "We the People") means to them and what they thought it meant to the Founding Fathers. In this activity, the instructions for the assignment explicitly directed students to tell the story of "We the People" both in the past and the present. Storytelling elements occurred in other activities as well. For example, the election "experiment" activity described above would not by itself relate to storytelling, but Jeff's instructions for processing this information did. In class, Jeff told his students to, "Think about patterns. What was going on if there was a year that doesn't fit the pattern for a particular state? Would that also apply to this state in 2016, or do you think they're likely to go with the same pattern? Tell the story of the election as you see it." To Jeff, the story he wanted students to interpret and explain was the trends in states' voting histories and how predictions could be made by analyzing their voting narratives.

In his interview, Jeff clarified that technology had many uses in his classroom, but specifically cited the ability to have students click on specific primary sources he wanted them to read for in-class discussion, as well as the ability of students to use technology to create and submit projects such as the "We the People" documentary cited above, which required students to submit a video of their reports on their class webpage. In this way, Jeff controlled and harnessed the way students used technology, and it gave him the ability to seamlessly blend technology into his already engaging classroom.

Pedagogical Strategies. The emphasis on storytelling showcases the central role of literacy strategies in Jeff's course (Table 4: Uses of literacy). During one observation, Jeff's students did a close read of the Preamble to the Constitution (this was the lead-in activity to the "We the People" Documentary assignment mentioned above). Small groups of students were given a specific term of phrase from the Preamble to define and then were requested to develop 
and perform a skit for the rest of the class to demonstrate the meaning of their word in context. Following this assignment, they went word-for-word through the Preamble as a whole class, asking questions, paraphrasing, and building on their knowledge as they progressed through it. In his interview, Jeff also mentioned other strategies, including R.A.F.T. writing prompts that had students "be in 1770 Boston writing a letter to 1770 Georgia" and "developing their own declaration of independence or creating their own bill." ${ }^{20}$ Jeff used these writing prompts to promote his students disciplinary writing of social studies content, which had implications for making the writing experience meaningful and memorable - like a well-known story.

Jeff's teaching style aligns very strongly to the C3 framework as well, but in a different way than Lisa's teaching. The construct of social studies as story priorities the idea of interpretation, decisions about inclusion vs. exclusion of sources, and a specific type of conclusion that is communicated. The nuances of teaching style do not change the fact that the students in Jeff's class are also expected to ask questions, use disciplinary tools to answer them, closely evaluate sources and evidence, and communicate their conclusions. However, the construct of the "story" means that a product in Jeff's class is more likely to "communicate conclusions" rather than "take informed action."

\section{Jacob: Relevant and Practical}

Teaching Philosophy. Jacob's beliefs about teaching social studies revolved around the idea that learning the content affords students so many opportunities to practice skills that are relevant and authentic. For example, Jacob spoke of the need to understand the context and background of a speaker in order to understand the speaker's comments and how to interpret

\footnotetext{
${ }^{20}$ K. Brimijoin, “Differentiation and High-Stakes Testing: An Oxymoron?", Theory Into Practice, 44, no. 3 (2005).
} 
them. During his interview, Jacob spoke frequently about students being able to use social studies skills such as interpretation and synthesis of a variety of sources outside of the classroom, particularly as they consider current events nationally and around the world. As he put it: "The life skills that I'm hoping for is that they would be able to read something, understand what the biases are, understand what the goal is, and then understand the creation of that product [the text]."

During our observations, Jacob was implementing a fully online unit, so his pedagogical style was largely reflected in the assignments students were required to accomplish as part of that unit. In his class, students would walk into his classroom, log into their accounts, and immediately begin work on their units. All readings were accessible online, all activities were to be conducted using technology, and all assignments were to be posted to their class webpage. In Appendix 2's example unit, the pedagogical framework underlining Jacob's teaching emerge.

- Learning objectives are divided into skills:

- ex. "Use questions generated about multiple historical sources to pursue further inquiry and investigate additional sources"

- Skills are divided into content topics between which students may choose:

- ex. Women and WWII; Eleanor Roosevelt's Four Basic Rights

- Content topics are divided into assignments:

- (ex. "Read the introduction to this primary source. Underline the main ideas and circle key words...Read the letter from Eleanor Roosevelt to Addie Frizelle...attempt to recreate the letter that was written by Addie Frizelle to which Eleanor was responding...Find at least 2 additional sources that demonstrates or 
discusses how Mrs. Roosevelt hoped to use her position as First Lady to support her four basic rights to improve the lives of African-Americans").

The tight organization is key for this online unit to work. Before implementing it, Jacob must organize the sequence of learning activities, design assessments and activities, and select the appropriate resources and scaffolds needed to complete the assignments.

One additional aspect of his pedagogical style is a belief in student choice. Students may choose which content topic they want to cover, and often inside content topics students can choose between a variety of assignments or resources. Students may work at their own pace, and submit assignments as they are ready as long as all of the assignments are submitted by the end of the unit. This provides students with more freedom and autonomy than in most face-to-face only classrooms, including those of the other two teachers highlighted here. Jacob's pedagogical style was defined during this unit as very student-centered and engaging. He walked around and interacted with each individual as an individual, and this unit was designed to meet the needs of a variety of students.

Technology Use. Of the three participants, Jacob's course was the most heavily reliant on technology during this online-only unit, so it's not surprising that Jacob cited perceived uses of technology including finding content, differentiation, and demonstrating content knowledge. However, Jacob also raised the most concerns among the participants about the use of technology in his interview. His concerns included issues such as 1 . the amount of class time eaten up by getting students started on their computers in class, 2 . the demands of keeping up with changing and new technologies, and 3. difficulties encountered trying to keep the class in roughly the same place when flipping a classroom. Perhaps most interesting given his complex online unit during the observation period is comments he made such as this: "I like technology 
when it's appropriate, but sometimes kids like to have a piece of paper that they can manipulate." Jacob's perceptions of technology as both useful and limiting have interesting implications in terms of the place of technology in teaching. Much like Jeff's use of technology, Jacob's organized online unit clarified and detailed precisely which websites, resources, and activities students were to do online, as well as how they needed to document their work. His concerns about technology led to a system where students' uses of technology were fairly tightly controlled, despite a variety of student choice in terms of content and activities.

Pedagogical Strategies. Jacob's uses of literacy and technology dovetailed meaningfully and demonstrated effective pedagogy. The technology allowed him to require students to read a variety of sources at their own pace and students utilized it to demonstrate their understandings using an activity of their choice. The wide variety of products students could create as formative assessments was steeped in literacy practices and included graphic organizers, "video vocabulary," photo story, mosaics, creative writing pieces, small group reports detailing a group's answer to a difficult historical question, and so on.. The Depth of Knowledge levels demonstrated in such assignments were high ${ }^{21}$, and students were required to individually complete assignments at their own pace. The heavy emphasis on understanding sources and evidence compliments Jacob's philosophy of teaching social studies, and it demonstrates how he incorporated technology and literacy as tools to accomplish his goals. As he stated: "[I think it's important] just to understand how the data is being manipulated so they can take this information in their lives and use it outside of my classroom."

\footnotetext{
${ }^{21}$ N.L. Webb, "Depth of Knowledge Levels for Four Content Areas," Orleans Southwest Curriculum Framework, last edited 2012, http://ossucurr.pbworks.com/w/file/fetch/49691156/Norm\%20web\%20dok\%20by\%20subject\%20area.pdf.
} 
Similar to Jeff's class, Jacob's teaching style prioritizes the interpretation of sources and evidence over other aspects of the $\mathrm{C} 3$ framework. However, the kinds of informal assessments required in this course have more in common with Lisa's prioritizing of the C3 Framework's $4^{\text {th }}$ dimension, communicating conclusions and taking informed action. Jacob wants students to be able to learn beyond the content, into other aspects of life, which is supported by the C3 Framework.

\section{Discussion}

Using TPACK as a way to analyze teachers' instruction provides a compartmentalized frame for dissecting instruction. With it, we attempted to pull the proverbial yoke from the baked cake in that we isolated the individual components of our participants' knowledge of content, technology, and pedagogy. To begin with Content: as researchers, we accepted that our participants had content knowledge of their subject in order to earn their South Carolina teaching licenses, gain a position teaching at this school, and were recommend by the district's social studies coordinator. Our interest, however, was to see how they build their students' content knowledge through their pedagogy in ways that promoted readiness for college, career, and civic life.

Moving on to Pedagogy, the intersection of pedagogical and content knowledge represented high-quality teaching in the 20th century. ${ }^{22}$ This intersection demonstrated how teachers could craft engaging learning experiences for their students when they understood both the content they teach and designed learning activities that had students engage the content using

\footnotetext{
${ }^{22}$ L.S. Shulman, "Those Who Understand: Knowledge Growth in Teaching," Educational Researcher 15, no. 2 (1986).

L.S. Shulman, "Knowledge and Teaching: Foundations of the New Reform," Harvard Educational Review 57, no. 1 (1987).
} 
higher-order thinking skills. In our study, we saw our participants lead their students to and through this intersection using a variety of methods. The point is not only that there are a variety of ways of designing this quality of instruction, it is also that the instruction is able to honor both the teacher's philosophy about teaching and the content while preparing students for college, career, and civic life. ${ }^{23}$ We posit that if other researchers were to replicate our study, they would find other "effective "social studies teachers who engage students at this intersection of pedagogy and content using different methods but that those methods are still anchored in both the teacher's philosophy and the tenets of the C3 framework. Technology, on the other hand, represents something different and disparate.

In their seminal paper, Mishra and Koehler discuss different technologies inclusive of hardware, software, and web-based tools and then state, "since technology is continually changing, the nature of TK [technological knowledge] needs to shift with time as well."24 The component that is missing from their articulation of technological knowledge is the purpose regarding how technology is used. When Cherner and Smith reconceptualized TPACK, they explained that technology must be evaluated not on the fact that it is being used in the classroom but rather based on how students are using it. ${ }^{25}$ To guide this thinking, they ask questions such as: Are students replicating a paper-and-pencil task using technology and Is technology being used to provide a learning experience that only can exist in the digital realm? In this study, questions regarding how effectively the participants used technology remain. For example, Lisa's use of the Silent Seminar provided students an avenue for thinking and exchanging ideas

\footnotetext{
${ }^{23}$ P.J. Palmer, "The Heart of a Teacher Identity and Integrity in Teaching," Change: The Magazine of Higher Learning 29, no. 6 (1997).

${ }^{24}$ P. Mishra and M.J. Koehler, "Technological Pedagogical Content Knowledge: A Framework for Integrating Technology in Teacher Knowledge," Teachers College Record 108, no. 6 (2006), p. 1027-1028.

${ }^{25}$ T. Cherner and D. Smith, "Reconceptualizing TPACK to Meet the Needs of $21^{\text {st }}$ Century Education," (in press, The New Educator, 2015).
} 
with their classmates. Previous to Google Docs, Lisa could have required her students to each write a comment on the whiteboard and then write comments back to their classmates. With Google Docs, Lisa was able to have all her students complete those actions digitally. In this example, the Google Docs increased the productivity of the activity, but it did not necessarily increase the way students collaborated.

The suggestion here is not that all uses of technology need to exist only in the digital realm to be effective, only that this is a layer of thinking about technology that not even these effective teachers fully considered. Although Lisa had her students use technology to complete higher-order thinking tasks using the Silent Seminar, it is possible that an additional technological task-perhaps engaging the students' collaborative skills further using social media tools, discussing content issues with an audience beyond the reach of the classroom--might've boosted the students' abilities to engage with the content even further in ways not possible using non-technological means. For this reason, critiques of the effectiveness of different instructional strategies that are based in technology represent an area for future studies.

\section{Conclusions}

The significance of these findings is the hopeful message that there is no magic formula for incorporating literacy and technology into social studies teaching, and there does not have to be. The effective teachers in this study used both literacy strategies and technology as tools when appropriate, and they were clear in their interviews that they believed there were times when these were appropriate tools, and times when they were not. This was especially true for technology, of which all three teachers expressed caution even as they incorporated technological elements skillfully into their activities (see Table 5: Perceived limitations and uses of technology). 
The teachers in this study were placed in a context where they had access to significant and high-quality professional development, as well as easy access to tablet and other technologies for their students. And yet, the emphasis and focus of their teaching was always on their content, undergirded by their own philosophies of what it means to teach social studies. Literacy strategies were used as common tools for helping students accomplish (and retain) content, but the emphasis in the end was the content itself - how much did they know and could they apply what they know to other situations and other subjects? While the teachers saw the value in using literacy strategies and integrated them skillfully and often into their instruction, they used them to promote the reading and writing of social studies content in their classroom. The participants did not see themselves as "reading teachers;" they saw themselves as social studies who taught disciplinary literacy.

The same can be said of technology. A common thread linking the teachers' use of technology is that it was considered useful only in particular circumstances and with particular tasks assigned. Their students were never given free reign with a computer or tablet to "research" a topic without specific guidance about what and where they were to research. Alternatively, the technology inclusion was often not about "research" at all, it was about collaborating with peers (e.g., Lisa's use of Google Docs) or creating a product (e.g., Jeff's "We the People" documentary). In every case, technology's use was strictly controlled by the teachers, with intended uses and outputs clear from the beginning and products closely monitored by teachers. Technology was viewed and used as a tool, but as a tool for teachers (knowledgeable about the technology's uses and abuses) and only secondarily as a controlled tool for students to accomplish specific tasks. 
The message of this study is that effective teachers are able to balance a variety of demands by maintaining perspective on what ultimately matters: the learning goals for their students. The pressures of teaching can be overwhelming, but the effective teachers in this study managed those expectations by staying true to themselves and their own beliefs about effective social studies instruction. 


\section{Bibliography}

Azlina, N.N. and A. Nik. "CETLs: Supporting Collaborative Activities Among Students and Teachers Through the Use of Think-Pair-Share Techniques." International Journal of Computer Science Issues 7, no. 5 (2010): 18-29.

Brimijoin, K. "Differentiation and High-Stakes Testing: An Oxymoron?” Theory Into Practice, 44, no. 3 (2005): 254-261.

Carspecken, Phillip. Critical Ethnography in Educational Research: A Theoretical and Practical Guide. New York: Routledge, 1996.

Cherner, T. and D. Smith. "Reconceptualizing TPACK to Meet the Needs of $21^{\text {st }}$ Century Education." In Press, The New Educator, 2015.

Cochran, K. F., Deruiter, J.A. Deruiter, and King, R.A. "Pedagogical Content Knowledge: A Integrative Model for Teacher Preparation," Journal of Teacher Education 44 (1993): 263-272.

Glaser, B. G., and A. L. Strauss. Discovery of Grounded Theory: Strategies for Qualitative Research. Chicago: Aldine Publishing Company, 1967.

Hausfather, S.. "Where's the Content? The Role of Content in Constructivist Teacher Education.” Educational Horizons 80 (2001): 15-19.

Haycock, K. "Good Teaching Matters: How Well-Qualified Teachers Can Close the Gap." Thinking K-16 3, no. 2 (1998).

Koehler, M., and P. Mishra. "What is Technological Pedagogical Content Knowledge (TPACK)?" Contemporary Issues in Technology and Teacher Education 9, no. 1 (2009): 60-70.

Kuhn, T.S. The Structure of Scientific Revolutions. Chicago, IL: University of Chicago Press, 2012.

Magnusson, S., J. Krajcik, and H. Borko. "Nature, sources, and development of pedagogical content knowledge for science teaching," In Examining Pedagogical Content Knowledge, edited by J. Gess-Newsomen \& N. G. Ledermen, 95-132. Netherlands: Springer, 1999.

Martin, D., and S. Wineburg. "Seeing Historical Thinking." The History Teacher 41, no. 3 (2008): 1-15.

McTighe, J. and F.T. Lyman. "Cueing Thinking in the Classroom: The Promise of TheoryEmbedded Tools.” Educational Leadership 45, no. 7 (1988): 18-24. 
Mishra, P. and M.J. Koehler. "Technological Pedagogical Content Knowledge: A Framework for Integrating Technology in Teacher Knowledge." Teachers College Record 108, no. 6 (2006): 1017-1054.

Moje, E. B. "Developing Socially Just Subject-Matter Instruction: A Review of the Literature on Disciplinary Literacy Teaching." Review of Research in Education 31, no. 1 (2007): 1-44.

National Council for the Social Studies. The College, Career, and Civic Life (C3)Framework for Social Studies State Standards: Guidance for Enhancing the Rigor of K-12 Civics, Economics, Geography, and History. Silver Spring, MD: NCSS, 2013.

Palmer, P.J. "The Heart of a Teacher Identity and Integrity in Teaching." Change: The Magazine of Higher Learning 29, no. 6 (1997): 14-21.

"Project Citizen Overview." Center for Civic Education. Last modified 2014. http://www.civiced.org/pc-program.

Rosenblatt, L. M. The Reader, The Text, The Poem: The Transactional Theory of Literary Work. Carbondale, IL: Southern Illinois University Press, 1978.

Shanahan, T., and C. Shanahan. "Teaching Disciplinary Literacy to Adolescents: Rethinking Content-Area Literacy." Harvard Educational Review 78, no. 1 (2008): 40-59.

Shulman, L. S. "Those Who Understand: Knowledge Growth in Teaching." Educational Researcher 15, no. 2 (1986): 4-14.

Shulman, L.S. "Knowledge and Teaching: Foundations of the New Reform." Harvard Educational Review 57 (1987): 1-22.

Sparks, D. "The Looming Danger of a Two-Tiered Professional Development System." Phi Delta Kappan 86, no. 4 (2004): 304-306.

Stronge, J.H. Qualities of Effective Teachers, $2^{\text {nd }}$ edition. Alexandria, VA: Association for Supervision and Curriculum Development, 2007.

Van Driel, J. H., N. Verloop, and W. de Vos. "Developing Science Teachers' Pedagogical Content Knowledge." Journal of Research in Science Teaching 35, no. 6 (1998): 673695.

Webb, N.L. "Depth of Knowledge Levels for Four Content Areas." Orleans Southwest Curriculum Framework. Last edited 2012. http://ossucurr.pbworks.com/w/file/fetch/49691156/Norm\%20web\%20dok\%20by\%20su bject $\% 20$ area.pdf. 
Wineburg, S., D. Martin, and C. Monte-Sano. Reading Like a Historian: Teaching Literacy in Middle and High School History Classrooms. New York, NY: Teachers College Press, 2011.

Yin, R. K. Case study research: Design and methods. $3^{\text {rd }}$ edition. Thousand Oaks, CA: Sage Publications, 2003. 